\title{
Grecka diaspora w Poznaniu w XVIII i XIX w.*
}

Dla Poznania wiek XVIII był bardzo burzliwym okresem. Liczne wojny, zaraza w 1709 r., wielka powódź z roku 1736 niszczyły miasto. Wiele wysiłku kosztowało przywrócenie mu dawnej świetności. Jednak trud się opłacił i z czasem Poznań stał się znowu miastem atrakcyjnym pod wieloma względami. Ład i spokój znacząco wpłynęły na ożywienie życia handlowego i bogacenie się mieszkańców. Obok obywateli narodowości polskiej licznie zamieszkiwali w Poznaniu przybysze z Niemiec, Szkocji, Włoch, Francji, Ormianie oraz Żydzi. Stał się też Poznań przystanią dla mniejszości greckiej.

Istnieją dwie główne przyczyny emigracji greckiej na tereny Rzeczypospolitej: 1) ekonomiczne - przede wszystkim handlowe; 2) polityczne oraz geopolityczne ${ }^{1}$.

Pierwszym etapem migracji Greków były tereny monarchii habsburskiej, a w szczególności miasta Królestwa Węgierskiego (Buda, Peszt, Miszkolc, Tokaj, Eger). Przyczynił się do tego pokój zawarty w Karłowicach w 1699 r. między Turcją a Austrią, Wenecją i Polską. Na mocy tego porozumienia Austria uzyskała ważne klauzule handlowe i religijne. Artykuł XIV głosił: „Niechaj nastanie wolny handel dla poddanych obu stron, zgodnie z wcześniejszymi świętymi traktatami, we wszystkich królestwach i podbitych terytoriach cesarzy, tak by można go było prowadzić w pożyteczny sposób, bez

* Skrócona wersja tekstu ukazała się na łamach Cerkiewnego Wiestnika: M. Mikołajczyk, Z dziejów greckiej wspólnoty w Poznaniu w XVIII i XIX wieku, „Cierkiewny Wiestnik” (Warszawa) 2014, nr 1, s. 15-23.

${ }^{1}$ S. Skarpelis-Sperk, Die griechische Diaspora in Deutschland, w: Griechische Migration in Europa. Geschichte und Gegenwart, red. E. Konstantinou, Frankfurt am Main 2000, s. 195. 
szalbierstwa i oszustwa z obu stron" ${ }^{2}$. Następnie grupy emigrantów skierowały się na ziemie Rzeczypospolitej. Szczególnie silne wspólnoty osiadły na terenie Wielkopolski, przede wszystkim w Kaliszu i Poznaniu. Regres gospodarczy, a co za tym idzie załamanie się handlu oraz upadek miast w Polsce okazały się sprzyjać przedsiębiorczym i obrotnym w handlu Grekom.

Niemały wpływ na emigrację miała zapewne sytuacja polityczna na Półwyspie Bałkańskim, a w szczególności terror turecki skierowany na ludność podbitych ziem. Pomimo stosunkowo dużej wolności religijnej, jaką cieszyła się grecka społeczność pod tureckim panowaniem, podlegała ona również wielu ograniczeniom podkreślającym ich status w państwie. Chrześcijanie nie mogli świadczyć przeciwko wyznawcom islamu w sądzie, nie mogli również wstępować w związki małżeńskie z muzułmankami. Chrześcijanin nie mógł nosić broni, a w zamian za to, że nie służył w wojsku, zmuszony był do płacenia specjalnego podatku, który w praktyce okazał się niezamierzonym przywilejem. Najbardziej uciążliwą powinnością dla społeczności podbitych przez Turków było pedomazoma, czyli pobór dzieci. Obowiązek ten egzekwowany z nieregularnymi przerwami zakładał oddawanie najdorodniejszych i najinteligentniejszych chłopców na służbę państwu tureckiemu w elitarnych oddziałach janczarów i w biurokracji sułtańskiej. Rozmaite formy dyskryminacji, jakim podlegali chrześcijanie, szczególnie gorliwie stosowane przez tureckie władze lokalne, prowadziły nieraz do indywidualnego lub zbiorowego przechodzenia na islam. Nieodosobnione były przypadki, że chrześcijanie oficjalnie przechodzili na wiarę Mahometa, by czerpać korzyści z przynależności do panującej religii, potajemnie natomiast nadal praktykowali prawosławie ${ }^{3}$.

Niezwykle interesującym problemem pozostaje pochodzenie etniczne emigrantów. W literaturze powszechnie używa się pojęć Grecy lub Macedończycy, traktując te dwa określenia równoznacznie, z naciskiem na niesłowiańskie pochodzenie emigrantów. W literaturze przedmiotu spotkać można kilka hipotez dotyczących ich pochodzenia. Jedną z nich wysunął Franio Ilesić. Twierdził on, że rodzina Żupańskich (a co za tym idzie i inni emigranci) pierwotnie była słowiańska, a nie grecka. Jako argument przytaczał fakt, że nazwisko to kończy się na -ski i jest charakterystyczne dla nazwisk pochodzenia słowiańskiego. Jednak jak słusznie zauważa Monika Romanowska, teza ta upada w świetle nieznanego Ilesićowi faktu, że Żupański spolszczył swe nazwisko najprawdopodobniej w 1794 r. , a Jan Konstanty Żupański, twierdził, że rodzice jego przybyli z Grecji ${ }^{4}$.

Autorem innej hipotezy jest Bohdan Baranowski. Twierdzi on, że kupcy, którzy dotarli do Polski, byli Słowianami, prawdopodobnie Bułgarami

${ }^{2}$ Cyt. za: B. Jelavich, Historia Bałkanów. Wiek XVIII i XIX, przeł. J. Polak, K. Salawa, Kraków 2005, s. 75.

${ }^{3}$ R. Clogg, Historia Grecji nowożytnej, przeł. W. Gałąska, Warszawa 2006, s. $24-25$.

${ }^{4}$ M. Foć, M. Romanowska, Jan Konstanty Żupański. Życie i dzieło, Poznań 1996, s. 11-12. 
z Adrianopola oraz Płowdiwu. To, że podawali się za Greków, wynikało z tego, że świadomość narodowa Bułgarów w XVIII w., nie była jeszcze wykształcona. Bułgarzy czuli się związani przede wszystkim z Cerkwią, nie zaś z jakąkolwiek grupą narodowościową. Dlatego też znaczna część zamożniejszych kupców bułgarskich podawała się za Greków i, niezależnie od nazwiska słowiańskiego, używali drugiego o greckim brzmieniu ${ }^{5}$. Znamienny jest fakt iż, kupców bułgarskich, posługujących się często językiem greckim (w mowie i piśmie), władze tureckie nazywały wprost Grekami ${ }^{6}$.

Kolejną tezę zamieścił w „Kurierze Poznańskim” autor występujący pod inicjałami A.S. Twierdził on, że poznańskiej wspólnoty nie tworzyli Grecy (byli tak tylko nazywani w różnego rodzaju dokumentach), a Arumuni (zwani też Rumuno-Wołochami) ${ }^{7}$. Trochę dalej w swych rozważaniach na temat pochodzenia Greków poszedł Sławomir Przygodzki. Przyjął on, że emigranci rekrutowali się głownie spośród najbardziej aktywnej ekonomicznie ludności słowiańskiej (macedońskiej) i wołoskiej. Wskazał, że za niegreckim rodowodem emigrantów przemawiają informacje dotyczące miejsc urodzenia emigrantów; pojawiające się najczęściej miejscowości to: Bitola, Korce oraz Moskopole. Za słowiańskim rodowodem przemawiać też ma bardzo szybka polonizacja tej grupy ludności oraz zaniechanie języka greckiego na rzecz polskiego ${ }^{8}$. A z racji wcześniejszego zamieszkania emigrantów w Macedonii, możemy mówić o Macedończykach, tak jak mówimy o Wielkopolanach czy Ślązakach9. W opozycji do tez A.S. i Sławomira Przygodzkiego sytuuje się twierdzenie Elżbiety Chadzinikolau, która za błędne uważa identyfikowanie emigrantów z Arumanami albo Macedończykami. Wskazuje przy tym, że miejscowości wymieniane przez A.S. (Przygodzki wymienia te same) leżą w północno-zachodniej Macedonii greckiej, a więc byli to rodowici Grecy. Według autorki, jeszcze dziś spotkać można tam te same nazwiska, które nosili emigranci przybyli do Poznania i Kalisza ${ }^{10}$. Poznańska wspólnota, podobnie jak inne w Rzeczypospolitej, nie stanowiła na pewno monolitu narodowościowego. Pamiętać jednak trzeba, że emigranci byli dla mieszkańców Poznania "Grekami” i nikt nie wnikał w subtelności pochodzenia narodowe-

${ }^{5}$ B. Baranowski, [rec.] W. Rusiński; Życie codzienne w Kaliszu w dobie Oświecenia. Poznań 1988, „Rocznik Kaliski” 1991, t. XXII, s. 225-226.

${ }^{6}$ T. Wasilewski, Historia Bułgarii, Wrocław 1988, s. 140; A. Garlicka, Bałkany a Europa w XIX i XX w., w: Dziesięć wieków Europy. Studia z dziejów kontynentu, pod red. J. Żarnowskiego, Warszawa 1983, s. 366-367.

7 A.S., "Arumuni” w Poznaniu, „Kurier Poznański” 1935, nr 123.

8 S. Przygodzki, Społeczność emigrantów macedońskich w Kaliszu w XIX wieku, w: Kalisz miasto otwarte, pod red. K. Walczaka i E. Andrysiak, Kalisz 2006, s. 56-57.

${ }^{9}$ S. Przygodzki, Kalisz wielokulturowy, Kalisz 2012, s. 105; S. Przygodzki, Jak kształtowat sie Kalisz wielokulturowy, „Spotkania z Zabytkami” 2011, nr 5-6, s. 20.

${ }^{10}$ E. Chadzinikolau, Początki i rozwój diaspory greckiej w Poznaniu w XVIII w., „Kronika Miasta Poznania" 1993, nr tematyczny Karol Marcinkowski i jego czasy, s. 265. 
go. Jak zauważa Andreea Iancu, w tych czasach za "Greka" uznawano nie tylko należącego do tego etnosu, lecz każdego, kto związany był z orientalną kulturą chrześcijańską. W społeczeństwie, które przywiązywało szczególną wagę do przynależności religijnej, narodowość zdawała się drugorzędna. Grecy, Serbowie, Bułgarzy lub Rumuni byli wszyscy synami jednego Kościoła - prawosławnego. Podział etniczny miał raczej znaczenie praktyczne, określał miejsce pochodzenia i używany język, ale ważniejszymi kategoriami identyfikacji były zawód i przynależność religijna. Zatem "Grekami" nazywano ogół kupców, niezależnie od tego, czy byli Serbami, czy Bułgarami, ponieważ mówili po grecku, w języku swej profesji ${ }^{11}$. W języku, który stał się lingua franca bałkańskiego handlu.

Pierwsze wzmianki o Grekach w mieście pochodzą z XVI w. W tabeli pogłównego z 1590 r. wymienieni zostali dwaj Grecy, którzy na ul. Wronieckiej "maumazyę mają"12. W tym samym czasie mieszkał w Poznaniu Jakub Berkentini z wyspy Cephalonia ${ }^{13}$. Ponownie, już znacznie liczniej, pojawili się Grecy w mieście w drugiej połowie XVIII w. W 1755 r. na Chwaliszewie znajdowały się sklepy win należące do kupców pochodzenia greckiego: Tomasza Róży, Teodora Mukułowskiego, Anastazego Grabowskiego, Jerzego Grabowskiego oraz Jerzego Szabelskiego. W 1756 r. prawa miejskie otrzymał Grzegorz Szabelski. W 1780 r. obywatelstwo miejskie otrzymali: Atanazy Szabelski, Konstanty Tuszyński, Dymitr Żupański i Dymitr Wretowski, natomiast w 1781 r. Dymitr Kałuba, Teodor Żupański oraz Grek Martin. W roku 1784 Grzegorz Lepory, w dwa lata później Dymitr Grabowski, a w 1788 r. Michał Dziemowski ${ }^{14}$.

Głównym zajęciem kupców greckich był handel winem węgierskim, stąd też nazywano ich nieraz Węgrzynami ${ }^{15}$. Oprócz win przywozili ze sobą również towary wschodnie: safiany, tytonie tureckie, lulki, cybuchy, owoce suszone, oliwę i szable damascenki ${ }^{16}$. Handel winem był bardzo opłacalny, nie dziwi więc, że w jego sprzedaży wykwalifikowali się greccy kupcy. Odgrywał on ogromną rolę i zajmował stale rosnącą pozycję w obrocie towarowym

11 A. Iancu, Fanarioci a początki nowoczesności na ziemiach rumuńskich, „Mówią Wieki” 2010, nr specjalny Historia Rumunii, pod red. J. Krawczyka, s. 32-33.

12 J. Łukaszewicz, Obraz historyczno-statystyczny miasta Poznania w dawniejszych czasach, t. I, Poznań 1998, s. 77.

${ }^{13}$ M. Wicherkiewiczowa, Grecy w Poznaniu, w: Obrazki z przeszłości Poznania, Poznań 2002, s. 50 .

${ }^{14}$ M. Foć, M. Romanowska, dz. cyt., s. 17.

${ }^{15} \mathrm{Z}$ tą nazwą związana jest ciekawa anegdota, mianowicie pewnego czasu pani Podstolina, bawiąc w Poznaniu w czasach transakcji świętojańskich, poleciła swemu hajdukowi zaprosić na obiad księdza Węgierskiego. Tymczasem hajduk pobiegł po misjonarza dyzunitę, który zaskoczony zaszczytem podążył na obiad. Zdziwiona pani domu na próżno oczekiwała księdza Węgierskiego, do czasu aż pomyłka się wydała, zob.: M. Wicherkiewiczowa, dz. cyt., s. 53.

${ }^{16}$ J. Leitgeber, Z dziejów handlu i kupiectwa poznańskiego za dawnej Rzeczypospolitej Polskiej, t. I, Poznań 1929, s. 123. 
Poznania. Obejmował swym zasięgiem cały rynek regionalny, a szczególnie miasta zachodniej i południowo-zachodniej Wielkopolski. Grecy sprowadzali wino najczęściej z ośrodków węgierskich: z Egeru, Tokaju, Miszkolca, Pesztu oraz z Wiednia, zakupywali również wina od kupców krakowskich. Znany jest fakt ekspedycji przez Greka Dymitrego z Chwaliszewa dwudziestu beczek wina do Szczecina ${ }^{17}$.

Od chwili swego przybycia Grecy postrzegani byli przez rodzime kupiectwo jako czynnik niepożądany. Powodowane to było tym, że w początkowym okresie przybywali sami, bez żon i rodzin, a zdobyte majątki w znacznej części wysyłali do ojczyzny. Grecy również swym profesjonalnym kupiectwem, pracowitością i oszczędnością nieraz szkodzili poznańskim kupcom zrzeszonym w Konfraterni Kupieckiej. Księgi tej instytucji przepełnione są skargami na przybyszów z południa. I tak wniosła Konfraternia skargę do sądu asesorskiego w Warszawie przeciw Jerzemu Rozie i Janowi Koźmie oraz innym Grekom handlującym w Poznaniu o przekroczenie praw i konstytucji państwowych. Jednak proces nie wypadł po myśli Konfraterni, oskarżeni handlarze uzyskali wynik dla nich korzystny, uchylony jednak przez króla Augusta II 30 lipca 1731 r. ${ }^{18}$ Jak długo trwał i z jakim skutkiem zakończył się ten proces, nie wiadomo. Natomiast $\mathrm{z}$ innego skryptu, zachowanego w archiwum korporacji, dowiadujemy się, że August III poparł prawa i przywileje Konfraterni osobnym reskryptem, własnoręcznie podpisanym i przesłanym do burmistrza, rady miejskiej i całego magistratu Poznania 7 października 1750 r. W dokumencie tym „[...] powiada król, że donieśli mu jego doradcy, na prośbę starszych i całej Konfraterni Kupieckiej miasta Poznania, jaki uszczerbek różni obcy kupcy, a zwłaszcza Grecy, przynoszą prawom i przywilejom łaskawie od poprzedników jego, królów polskich, tejże Konfraterni nadanym. [...] Wobec tego król, uproszony ażeby seniorów i całą Konfraternię zachował przy jej przywilejach i nie pozwolił jej krzywdzić, zważywszy, że sąsiednie miasta upadły wskutek konkurencji obcych kupców i Greków, chce zapobiec iżby podobnemu losowi nie uległ także Poznań, więc polecił jego radzie miejskiej i magistratowi, by stosując się do praw i przywilejów przyznanych Konfraterni Kupieckiej, nie pozwalali odtąd trudnić się handlem żadnemu z obcych przybyszów, a nawet mieszkańców m. Poznania, któryby nie posiadał prawa miejskiego i nie należał do Konfraterni"19. Nie spoczęli w swych zabiegach Grecy i za wstawiennictwem metropolity lwowskiego starali się, aby za pośrednictwem Stolicy Apostolskiej uzyskać dokument pozwalający im otrzymać prawa miejskie i dostęp do bractw kupieckich na terenie Rzeczypospolitej. Także te zabiegi zostały storpedowane przez członków

${ }^{17}$ K. Kuklińska, Handel Poznania w drugiej połowie XVIII wieku, Warszawa-Poznań 1976, s. 83.

18 J. Leitgeber, dz. cyt., s. 123-124.

19 Tamże, s. 125. 
Konfraterni poznańskiej ${ }^{20}$. Starania bractwa kupieckiego w walce z Grekami odnosić musiały jednak pożądane skutki, o czym świadczy deklaracja, jaką greccy kupcy złożyli w poznańskim ratuszu 29 października 1752 r. Czytamy w niej: „My niżej wyrażeni dajemy tę asekurację i submisję na osoby nasze przezacne sławnemu Bractwu Kupieckiemu miasta JKról. Mości Poznania: iż lubo uprosiliśmy sobie $\mathrm{w}$ teraźniejszych czasach wojennych dla większego bezpieczeństwa miejsce do złożenia win węgierskich wozów ośm In clarissimo Collegio Ichm. Ojców Jezuitów poznańskich, na których wozach znajduje się beczek siedmdziesiąt, tych win nikomu innemu przedawać ani przez siebie ani przez inne jakiekolwiek osoby subordynowane nie będziemy, tylko panom kupcom tutejszym poznańskim do handlu swego onychże potrzebującym, a gdybyśmy tych win tu w mieście Poznaniu nie mogli sprzedać, tedy ich stąd wywieść do innego miasta będziemy powinni; In casu vero contraventionis wolno będzie Ichm. Panom starszym kupieckim, osoby nasze i towary nasze sekwestrować i na ratuszu poznańskim zatrzymać". Oświadczenie podpisali Jerzy Kopimay i Aleksander Sewery ${ }^{21}$. Tymczasem magistrat poznański, w którego ręku spoczywała władza wykonawcza, nie spieszył się w wykonywaniu wyroku królewskiego przeciwko Grekom. Dlatego Konfraternia wystosowała do kanclerza Jana Małachowskiego list następującej treści: „Są Miłościwy Panie konstytucje koronne, że tam tylko ludziom ritus gracie czy uniti czy disuniti wolno commercial prowadzić, gdzie cerkwie ich zasięgały, atqui w Poznaniu żadnej nie ma, więc sprawiedliwie tu trybem kupieckim bawić się, ani do Bractwa Kupieckiego takowi ludzie przypuszczeni być nie mogą, na co i reskrypt od Najjaśniejszego Pana przeciwko Grekom mamy, którzy po tylu miejscach przysposobiwszy sobie fortuny i długów narobiwszy, jako się w Kaliszu stało, wynieśli się prywatnie do ojczyzny swojej lub ad alias regiones"22. Aby pozyskać względy kanclerza, Konfraternia ofiarowała jego żonie kosz jabłek.

Jak bardzo Grecy znienawidzeni byli przez kupiectwo poznańskie, może świadczyć fragment listu do Wojciecha Miaskowskiego, chorążego kaliskiego z 1 listopada 1775 r., w którym kupcy z Poznania m.in. pisali: „[...] abyś Miłościwy Panie i Dobrodzieju kaszącego się na ostateczne prawie nasze zniszczenie greczyna nie tylko animusz zganić, ale go też z kamienicy swojej alienować raczył" 23. Nie wiadomo, o kim była mowa i jak się sprawa zakończyła. Faktem jest, że konkurencja była trudna do pokonania dla miejscowego kupiectwa, Grecy bowiem, sprzedając swoje towary „bez wszelkiego żądania i odezwy po stancjach, na całe miasto z próbkami wina obchodzą, gatunki wina swego przechwalają i pod pozorem gwałtownej potrzeby pieniężnej

\footnotetext{
20 Tamże, s. 126.

21 Tamże, s. 126-127.

22 Tamże, s. 127-128.

23 Tamże, s. 128.
} 
za tanią cenę wino spuścić przyrzekają, kupno nawet u niemyślących o kupnie wina wmawiają" ${ }^{24}$.

Nie najlepsze stosunki panowały też między Grekami a magistratem poznańskim. O stopniu konfliktu świadczyć może fakt zwrócenia się kupców greckich o pomoc do bp. Wiktora Sadkowskiego. Z inicjatywy magistratu, bez dostatecznych powodów, Greków poczęto prześladować i nazywać ich krzywoprzysięzcami, co podważało ich opinię wśród mieszkańców miasta. Doszło do bezczeszczenia grobów greckich i zwłok zmarłego księdza Feniksa ${ }^{25}$. Sekretarz magistratu Sobolewski obłożył sekwestrem majątek po zmarłym Tauszańskim na niekorzyść spadkobierców. Niedługo po tym zaczęto z magistratu szerzyć pogłoski jakoby Grecy otruli swego kapelana (poprzednika Chartofilaksa). Grecy złożyli protest przeciwko postępowaniu magistratu i Sobolewskiego, wpisali go do ksiąg grodzkich oraz złożyli skargę do koronnego sądu asesorskiego. Magistrat w odpowiedzi nakazał swemu instygatorowi pociągnąć Greków do odpowiedzialności, oskarżając ich o wyzywające postępowanie i nieposzanowanie magistratu. Gdy spór doszedł do sądów, Grecy, w obawie, że magistrat w tym czasie pozbawi ich prawa prowadzenia handlu, wysłali swych przedstawicieli do podkanclerzego koronnego bp. Macieja Garnysza, składając mu memoriał, w którym pisali, że uważają się za mocno pokrzywdzonych, obawiają się o swój los i proszą podkanclerzego, aby nakazał magistratowi powstrzymać się od decyzji co do skargi, do czasu aż sprawa nie zostanie rozpatrzona przez sąd grodzki, a następnie mieszany. 8 października $1788 \mathrm{r}$. podkanclerzy koronny przesłał magistratowi memoriał Greków wraz ze swoim pismem, w którym w imieniu króla polecał udzielić wyjaśnień co do wszystkich punktów memoriału i nie wzywać Greków do swego sądu, zanim wszczęty przez nich proces z magistratem nie zostanie rozpatrzony przez sąd asesorski. Po otrzymaniu tak pomyślnej decyzji Grecy 18 października wystosowali pismo do bp. Wiktora, załączając odpis wspomnianego memoriału oraz odpowiedź podkanclerzego, i prosili go, aby wystąpił do posła rosyjskiego z prośbą o interwencję. Zarazem Grecy informowali biskupa o stanie spraw parafii, zwracając się o pomoc w swych poczynaniach. Prosili o udzielenie zezwolenia na budowę świątyni, nadmieniając o podjętych już staraniach celem uzyskania przywileju królewskiego na świątynię, cmentarz i szkołę, o pozwolenie korzystania z urządzonego cmentarza, o błogosławieństwo na odprawianie nabożeństw w tymczasowej kaplicy i o udzielenie zezwolenia na piśmie ks. Chartofilaksowi na odprawianie nabożeństw i wykonywanie obowiązków proboszcza (Grecy prosili, aby korespondencja pisana była $\mathrm{w}$ języku polskim lub po łacinie; argumentowali to tym, że wszelkie urzędowe pisma wpisywane są do ksiąg grodzkich, a w magistracie poznańskim nikt nie zna greckiego ani „słowiańskiego języka”).

\footnotetext{
24 Tamże, s. 129.

25 E. Chadzinikolau, dz. cyt., s. 268.
} 
Popierając sprawy Greków, Wiktor wystosował dwa listy: do hr. Stackelberga i kanclerza koronnego, bp. poznańskiego Antoniego Okęckiego. Posła prosił o protekcję nad Grekami poznańskimi, a kanclerza o zapewnienie sprawiedliwego wyroku w ich sprawach, które toczyły się w sądach. W odpowiedzi przesłanej Grekom Wiktor wyraża im współczucie oraz zaleca cierpliwie znosić przykrości. W sprawie zezwolenia na budowę świątyni biskup oświadczył, że może być ono udzielone dopiero wtedy, gdy Grecy okażą przywilej królewski, taki sam przywilej powinni posiadać na cmentarz. Biskup zezwolił księdzu Konstantemu, zalecanemu przez Greków i posiadającemu pozytywną opinię od kapelana poselstwa rosyjskiego ihumena Gabriela, odprawiać nabożeństwa, jednakże pod warunkiem przedłożenia dekretu o wyświęceniu i zezwolenia od swego biskupa na wyjazd do innej diecezji. Pozwolenie na odprawianie nabożeństw w kaplicy, w której odbywały się one dotychczas, zostało udzielone ${ }^{26}$.

Dopiero ustawy działającej w Poznaniu Komisji Dobrego Porządku z 1780 r. uregulowały warunki pobytu Greków w mieście. Nakazano im zakup kamienic i placów. Zarówno handel, jak i kupno kamienicy miały dokonać się w oparciu o własne fundusze. Przy zakupie pustego placu Grecy musieli uzyskać poręczenie osiadłego mieszczanina lub szlachcica i na jego poczet wpłacić dziesięć tysięcy zł polskich. Grecy zobowiązani byli do prowadzenia handlu samodzielnie, bez wspólników spoza bractwa. Obowiązywał ich też, tak jak innych kupców handlujących winem, zakaz jednoczesnej sprzedaży trunków francuskich i węgierskich. Komisja zakazała również pod karą tysiąca grzywien przeprowadzania sądów wewnętrznych, częstych wśród Greków. Kupcy greccy, którzy nie podporządkowali się zarządzeniom Komisji Dobrego Porządku, musieli opuścić miasto po wyprzedaży zapasów wina. Próba wprowadzenia w błąd Komisji groziła konfiskatą mienia i natychmiastowym wydaleniem $z$ Poznania ${ }^{27}$. W niedługim czasie stali

${ }^{26}$ E. Sakowicz, Kościót prawostawny w Polsce w epoce Sejmu Wielkiego 1788-1792, Warszawa 1935, s. 74-76.

27 B. Tyszkiewicz, Komisja Dobrego Porzadku w Poznaniu 1780-1784, Poznań 2005, s. 49-50, 145-148, 169: „Greki i Wegry winem handlujący. Dla zapobieżenia kraiowemu zubożeniu, a ubezpieczenia należących korzyści kupcom obywatelom miasta, gdy się z lustracji okazało, iż grecy i węgrzyny winem handlujący, oprócz dwóch, prawa miejskiego ani posesyi nie maią, a przecież z handlu wina z pokrzywdzeniem bractwa kupieckiego zyskują, majątek zaś tym sposobem zgromadzony za granicę przesyłaią, postanowiono iest, iż którybykolwiek grek, czyli węgrzyn handel wina maiący, przed pierwszym miesiąca Kwietnia w roku 1780. prawa miejskiego i bractwa nie przyiąl, oraz posesji wymurowaney, kamienicy na dziedzictwo własnym majątkiem nie kupił, i w całości nie opłacił, tudzież z niey długów wszystkich, natychmiast nie oczyścił, lub przynaymniey placu dziedzicznym prawem nie nabył, a to w środkowym miasta okręgu, oraz za sobą, iż ten plac naydaley w przeciągu trzech lat w masyf zamuruje, rękojmi nie przystawił, i tego wszystkiego w pewnych dowodach przed Kommisyą na dzień wyżey wyrażony nie okazał, takowy każdy grek, czyli węgrzyn natychmiast wyprowadzić się z miasta i wina wyprzedać obowiązanym będzie. Ci zaś Węgrzy, którzy do prawa mieyskiego należą, i na po- 
się poznańscy Grecy właścicielami następujących kamienic w Rynku: Michał Karyłło - nr 88, Józef Pawłowski - nr 76, Mikołaj Tauszański - nr 74, Dymitr Kałuba - nr 60 i Teodor Żupański - nr 58 i 5928. W innych punktach miasta nabyli posesje: Lepory przy ul. Ślusarskiej, Iwanowicz przy ul. Wrocławskiej, Grabowski przy ul. Psiej (obecnie Szkolna), Wretowski i Dyzma przy ul. Wronieckiej, Konstanty Tuszyński przy ul. Świętosławskiej ${ }^{29}$.

Do Konfraterni Kupieckiej należeli przed rokiem 1794: Teodor Żupański, Demitry Kałuba, Mikołaj Moliński, Anastazy Szabelski, Jerzy Lepory, Konstanty Żupański, Michał Dziemowski, Konstanty Tuszyński, Demitry Grabowski, Mikołaj Tauszański, Michał Pawłowski, Jan Pawłowski, Tomasz Iwanowicz oraz Jerzy Żupański ${ }^{30}$. W 1795 r. do Konfraterni wstąpił Mikołaj Grabowski, syn zmarłego winiarza Demitrego ${ }^{31}$. W roku 1796 przyjęto Anastazego Tauszańskiego, syna kupca poznańskiego Mikołaja ${ }^{32}$. W 1800 r. szeregi Konfraterni Kupieckiej zasilił Anastazy Żupański, syn zmarłego Jerzego ${ }^{33}$.

tym pod wyżey oznaczonemi warunkami przyięci będą, do wszystkich praw i przywilejów stanowi miejskiemu służących przypuszczonemi bydź maią, a przy przyięciu do prawa miejskiego przysięgę wykonać powinni, iako z własnego tylko majątku, handel wina prowadzić maią, i do tego handlu, żadnych wspólników prawa miejskiego, i bractwa kupieckiego oraz osiadłości niemaiących nie przypuścili, ani przypuszczać będą. Co gdyby się na kogo pokazać miało, majątek iego cały oraz wspólnika do kassy mieyskiey skonfiskowany bydź powinien. Sądów żadnych prywatnych, ciż grecy winiarze pod karą tysiąca grzywien składać i miewać między sobą nie maią, lecz prawo miejskie i bractwo przyiąwszy zwierzchności mieyskiey, równie z inszemi obywatelami podlegać będą. Ci zaś grecy, którzy kamienice, lub place puste w mieście na własną osiadłość kupować będą, po zawartych tranzakcyach wykonać przysięgę maią, iako te kamienice lub place nie na zmowę kupili, ale wlasnym majątkiem zupełnie oręż zapłacili, ani na ich kupno żadnego długu nie zaciągnęli, oraz długi z nich gotowemi pieniędzmi swoimi zaspokoili. A gdy wspomnieni grecy winiarze dopełnienie wyż opisanych nakazów w złożonych przed Kommissyą dowodach okazali, i rzeczoną przysięgę wykonali, takowym dosyć uczynienie niniejszemu Kommissyi i rozrządzeniu przyznane iest. Dla pewnego jednak zwiedzenia stanu posesji przez tychże Winiarków nabytych, J.W. Gurzyński J.K. Mci Kommissarz uproszony, z przybranemi dwoma magistratowemi osobami i architektem pomienionych posessyi uczynił rewizyą, podług ktorey w exekucyi przepisów ninieyszey ustawy, dane są magistratowi od Kommissyi przyzwoite dyspozycyie, a dozor tego J.W. Generałowi Wielkopolskiemu poruczony. Na proźbę zaś iednego winiarza niemożnością kupienia dziedziczney posesji wymawiającego się, dozwolony mu iest czas do pierwszego miesiąca Kwietnia w roku 1780. wyprzedania wina swego, po którego wyjściu handel wina pod konfiskacyią iest mu zakazany, i wyprowadzenie się z miasta ostrzeżone.

Handel wina. Kupcy i Węgrzy winem Węgierskim lub Francuzkim handlujący, iednym tylko tegoż wina gatunkiem handlować odtąd maią, a to pod konfiskacyią iednego wina gatunku, którego mniey będzie".

${ }^{28}$ M. Foć, M. Romanowska, dz. cyt., s. 16.

${ }^{29}$ E. Chadzinikolau, dz. cyt., s. 268.

${ }^{30}$ J. Leitgeber, Z dziejów handlu i kupiectwa poznańskiego, cz. II, Czasy Prus Południowych $i$ Księstwa Warszawskiego (1793-1815), Poznań 1934, s. 33-34.

31 Tamże, s. 35.

32 Tamże, s. 35.

${ }^{33}$ Tamże, s. 36. 
W 1805 r. wstąpili do Bractwa Michał Karyłło z Macedonii oraz Grzegorz Szabelski, syn kupca Anastazego ${ }^{34}$. W czasach Księstwa Warszawskiego do Konfraterni Kupieckiej należeli: Demitry Kałuba (handel winem), Michał Karyłło (handel winami węgierskimi), Jerzy Lepory (handel winem), Michał Pawłowski (handel winem), Grzegorz Szabelski (handel winem), Konstanty Tuszyński (handel winami węgierskimi); Marianna Żupańska (wdowa), od roku 1813 Jan Żupański (handel winem) oraz Konstanty Żupański (handel winem $)^{35}$.

Przywiązanie Greków poznańskich do religii było bardzo silne. Mimo zmiany nazwisk, zawsze podkreślali, że są Grekami. Z wielką pieczołowitością kultywowali zwyczaje greckie oraz obrzędy i ceremoniał kościelny. 17 stycznia 1778 r. mieszkańcy Poznania byli świadkami (pierwszy i ostatni raz) ciekawego obrządku kościoła prawosławnego, Grecy po odprawieniu nabożeństwa w kamienicy Garczyńskich poszli w uroczystej procesji przy asystencji wojska rosyjskiego na most wielki przy przedmieściu św. Rocha i przy odgłosie salw z broni palnej oraz armat pop poświęcił Wartę.

Grecka gmina została założona najprawdopodobniej około 1750 r. Emigranci mieszkający w Poznaniu byli chrześcijanami wyznania prawosławnego, jak sami o sobie mówili "wyznania greckiego obrządku orientalnego". Nie byli grekokatolikami, tzn. unitami, a taki pogląd pokutuje jeszcze w wielu opracowaniach. Zgodnie z prawem kanonicznym, poznańska parafia musiała podlegać biskupowi miejsca. W związku z tym podlegała jurysdykcji biskupów bukowińskich (rezydujących w Czerniowcach w Austrii), węgierskich i greckich (patriarchat ekumeniczny w Konstantynopolu) ${ }^{36}$. Zależność ograniczona była do wyświęcania kapłanów i udzieleniu im błogosławieństwa przed objęciem danej cerkwi; nie udzielano kapłanom żadnych zaleceń co do sprawowania funkcji w poszczególnych parafiach.

Do 1802 r. zwierzchnictwo nad kaliską i piotrkowską wspólnotą posiadał protopop rezydujący w Poznaniu.

Głównymi opiekunami gminy od początku jej istnienia byli przedstawiciele rodziny Żupańskich ${ }^{37}$. Ufundowali oni pierwszą kaplicę w kamienicy Garczyńskich, następnie w 1793 r. , przeniesioną do kamienicy na Starym Rynku nr 74, a w 1819 na ul. Nową 2 - która przetrwała do chwili rozwiązania gminy greckiej przez ostatnich ich członków: Wacława, Jana i Stefana Żupańskich, w 1909 r. Jak podaje Maria Wicherkiewiczowa, kaplica była bogato, a nawet z przepychem urządzona, zdobiły ją liczne obrazy ze szkoły bi-

\footnotetext{
34 Tamże, s. 36.

35 Tamże, s. 194-195.

36 J. Raciborski, Monografja Kalisza, Kalisz 1912, s. 131.

37 M. Wicherkiewiczowa, dz. cyt., s. 53.
} 
zantyjskiej z bogatą dekoracją z pereł i haftów, starożytne ornaty, kielichy, księgi liturgiczne i mszały w pięknej oprawie ${ }^{38}$.

Duchowieństwo prawosławne dzieli się na "czarne" - są to kapłani celibatariusze, prawie zawsze mnisi, przed którymi droga awansu w cerkwi stała otworem i z nich zazwyczaj wywodzili się biskupi, oraz „białe” - należą do niego kapłani posiadający rodziny, którzy sakrament małżeństwa przyjęli przed święceniami diakonatu. Posiadamy niewiele informacji na temat kapelanów poznańskiej wspólnoty.

Pierwszym duchownym poznańskiej gminy, o którym posiadamy informację, był Atanazy Korda, mieniący się „kapelanem w mieście Poznaniu”. Następnym był protopop ${ }^{39}$ cerkwi województw wielkopolskich Konstantyn Chartofilax (Chartophilax) Okuta ${ }^{40}\left(\mathrm{Ukuta}^{41}\right)$. Pochodził z miasta Moskopole ${ }^{42}$. Był autorem wydanej w Wiedniu pracy pt. Nowa pedagogja czyli Elementarz łatwy do nauki dla matych dzieci, do nauki Romano-wołoskiej na pożytek powszechny Romano-Wołochów ${ }^{43}$. W 1798 r. podarował przetłumaczone przez siebie z języka greckiego na łacinę wiersze przebywającemu w Poznaniu ministrowi von Vossowi ${ }^{44}$. Brał czynny udział w obradach Kongregacji pińskiej w 1791 r. jako jedyny duchowny przedstawiciel województw wielkopolskich i prawdopo-

38 Tamże, s. 55.

${ }^{39}$ Dawne, wyszłe z użycia na początku XIX stulecia, określenie kapłana prawosławnego wyższego stopnia, sprawującego opiekę nad kilkoma parafiami. Protopop jest w Cerkwi prawosławnej odpowiednikiem dziekana kierującego dekanatem.

${ }^{40}$ E. Sakowicz, dz. cyt., s. 184.

41 A.S., dz. cyt.

${ }^{42}$ Nieistniejące dziś miasto w górach nad rzeką Devoll w południowej Albanii. Na jego miejscu znajduje się obecnie wieś Voskopojë w okręgu Korcza. Na początku XVIII w. Moskopole urosło do rangi ośrodka handlowego i kulturalnego znaczącego w skali Bałkanów, a nawet Europy. Miejscowi kupcy kontrolowali handel na całych Bałkanach, od Dubrownika do Konstantynopola, i wymieniali towary nawet z Niemcami i Wenecją. Okresem największego rozkwitu Moskopola była połowa XVIII w. Miasto zamieszkiwało wówczas sześćdziesiąt tysięcy osób, znajdowały się tu kamienne budynki i brukowane ulice. Działało wówczas wiele manufaktur i banków, drukarnia, a nawet grecka akademia - Hellênikon Frôntistêrio, istniejąca od 1744 r. Kończąca ją młodzież często kontynuowała naukę w przodujących ośrodkach Europy Zachodniej, a o Moskopolu mówiono jako o „drugich Atenach”, w uznaniu dla kontynuacji dzieła dydaktycznego dawnych Aten. Drukarnia w Moskopolu, założona około $1730 \mathrm{r}$. , była jedną z dwóch istniejących wówczas w imperium osmańskim. Wydawano tu wiele prac po grecku i po arumuńsku (alfabetem greckim), m.in. w 1770 r. ukazał się tu pierwszy nowożytny słownik języków bałkańskich: greckiego, albańskiego, arumuńskiego i bułgarskiego. Tu również wydano pierwszą gramatykę języka arumuńskiego. W mieście istniały 72 świątynie prawosławne i klasztory, działała szkoła ikonopisarstwa o specyficznym miejscowym stylu. Moskopole upadło wskutek serii najazdów albańskich i tureckich. W 1769 r. miasto splądrowały wojska osmańskie. W 1788 r. albańskie wojska Alego Paszy z Tepeleny spaliły miasto i wygnały jego mieszkańców. Do reszty Moskopole zostało zniszczone podczas I wojny światowej w 1916 r. Źródło: <www.wikipedia.org/wiki/Moskopole> (dostęp: 11 marca 2014 r. ).

${ }^{43}$ A. S., dz. cyt.

44 "Gazeta Południowo-Pruska" nr 46 z 9 czerwca 1798 r. 
dobnie wszystkich gmin prawosławnych założonych przez Greków ${ }^{45}$. Został wybrany jednym $z$ jedenastu asesoró $w^{46}$ Kongregacji. 2 lutego odprawił nabożeństwo w języku greckim. Jego mowa, wygłoszona w języku greckim 2 lipca, otwierała jedno z posiedzeń Kongregacji ${ }^{47}$. Zmarł "5 augusta 1799 r." 48 Stosunkowo najwięcej wiemy o następnym kapelanie poznańskiej wspólnoty - Atanazym Sawiczu. Z pochodzenia Serb, lingwista, zakonnik reguły św. Bazylego z monasteru św. Jerzego w Bogowadzia, urodził się w 1776 r. w mieście Novi w Dalmacji ${ }^{49}$. Tak oto opisuje podjęcie decyzji wyjazdu i podróż do Poznania: „[...] grecka Kompania wszakże obejść się nie mogła bez Xsiędza, w 1799 roku oświadczyli, że rok od zaniesienia Biskupowi Bukowińskiemu, że bez księdza są już ze dwa lata. Biskup jako chrześcijański pasterz, będąc gorliwym po Chrystusie - ubolewał bardzo sercem o utracie którą w tak oddalonym kraju mieli [...] bez zbawiennego Pastora [pasterza - M.M.] i na ten koniec wyznaczył wielu Xsięży aby pasterza nad waćpaństwem [chodzi o poznańską wspólnotę - M.M.] objął. Jednakże żaden człek nie miał chęci w tak dalekie Kraje jechać do czego według pewnych przyczyn przynaglać Biskup żadnego nie może, wiele czasu przeszło między wćpaństwa prośby nim pomyślny skutek dla nich nie odebrali. [...] która się gruntowała, że pragnąc pasterza okażą szacunek wysoki, miłość najszczerszą, roczna pasja przynajmniej 18 razy. Zważywszy te obietnice nie trzeba było wątpić o tym wcale więc z tych wszystkich wielu Ja ten był który zadecydował odpowiadać woli Jaśniewielmożnego Biskupa. Puściłem się więc w podróż i do Kraju mnie niewiadomego $\mathrm{w}$ czas kiedy niesłychane śniegi przywaliły drogi i kiedy mrozy do samego serca. Dopiero żałowałem [...] jednak wszystko to znosiłem lwim sercem. [...] i co miałem furmanowi zapłacić 10 dukatów byłem przymuszony z wielkim ambarasem 15 zapłacić, ponieważ on z półdrogi chciał nawrócić ku domowi nie chcąc za uczynioną drogę ode mnie wcale nic, byłem we Lwowie i w Warszawie i na ostatek zawitałem do Poznania, cóż mi się tu przytrafiło, Boże! Lepiej nie mówić, nie chce ja tu wspominać zaśnieci i mrozy i bezdroże które daleko gorzej od tamtych zastałem. Długo walczyłem sam z sobą i niedowierzałem nigdy własnym oczom w tym"50. Miał przebywać w Poznaniu trzy lata, został lat osiem. Jednak nie tylko mrozy i śniegi dały się

${ }^{45}$ E. Sakowicz, dz. cyt., s. 186. Przedstawicielami województw wielkopolskich oraz miast Poznania, Kalisza i Piotrkowa Trybunalskiego byli Anastazy Grabowski i Ambroży Franciszek Duczyński.

46 Tamże, s. 189, przyp. 1.

47 Tamże, s. 192. Tekst mowy pod tytułem Mowa miana na dniu drugim Julii roku 1791 w języku greckim przez X-a Konstantyna Kartofilaksa kapelana poznańskiego na polski jezzyk wyttumaczona i tymże językiem potem czytana", tamże, załącznik nr 4, s. 260-262.

48 Archiwum Państwowe Kalisz [dalej APK], Akta parafii obrządku grecko-katolickiego w Kaliszu, sygn. 3, s. 46.

49 J. Raciborski, dz. cyt., s. 131.

50 APK, dz. cyt., s. 21-23. 
poważnie we znaki Sawiczowi w Poznaniu. Chyba od samego początku nie układała się współpraca między kapłanem a jego „trzódką". Akta dotyczące kaliskiej wspólnoty przepełnione są zapisami dotyczącymi zatargów z poznańskimi Grekami. Po przybyciu do Poznania zaopiekował się Sawicz rodziną poprzedniego kapłana Chartofilaxa, który zmarł na krótko przed jego przyjazdem, w tej sprawie pisał nawet list do prezydenta Poznania von Vossa ${ }^{51}$. Sawicz, oprócz pełnienia posługi w Poznaniu, sakramentów udzielał również w Kaliszu i Gostyniu. W 1804 r. sakramentu chrztu udzielił Janowi Konstantemu Żupańskiemu. W czasie swojego kapelaństwa stał się Sawicz świadkiem rozłamu wśród członków poznańskiej diaspory. Tak oto relacjonował ją w jednym ze swoich pism do sądu: „z Kompanią w ciągu moich 8 laty Kapelaństwa miałem 3 kontrakty, po zakończeniu których zawsze Kompania okazała swe ukątętowanie [pisownia oryginalna - M.M.] z mego Kapelaństwa i zawsze $\mathrm{z}$ wielkimi ich prośbami przy nich $\mathrm{w}$ tejże powinności zostawałem [...] ja nie miałem żadnej potrzeby z ostatnich moich 2 lat zostać u nich za kapelana ponieważ kaliska grecka kompania ze mną była już zgodę uczyniła za kapelana, ale tutejsza kompania temu przeszkodziła gdyż przyobiecała mnie daleko większe za to korzyści oprócz wiadomej w kontrakcie moim pęsji, drzewo i wina jeszcze na żądanie moje i własny przybytek deklarowały mnie do Kalisza pojazdy i koni 4 razy do roku a to na własny ich koszt ${ }^{52}$, jednakże ja stałem się $\mathrm{w}$ tym oszukanym bo żadnego razu nie chcieli mnie onych dać i owszem gdym był proszony do Kalisza dać ślub kupcowi Adamoskiemu, wyraźnie mnie kompania tego zabroniła a przez to jestem stratny do 1210 i więcej dukatów. [...] Dyrektora Demoskiego na pewny czas za dyrektora ich dzieci oraz też za śpiewaka i czytelnika w kaplicy ich, w czasie jego Dyrektorstwa Kompania rozłączyła się na dwie części, jedni byli z niego kątęci a drudzy wymyślali na niego nieprzyzwoite nagany. Stąd wynikło, że wzmiankowany Dyrektor powodujący za opinią szczycącej jego strony opuścił kondycją podobną w Kaliszu, dla czego przymuszona była szczycąca jego strona osobną ugodę z nim czynić i utrzymać jego na pewny czas znowu na dyrektora, a ponieważ kontrująca strona dyrektorowi odmówiła pomieszkania w kamienicy kaplicznej dla tego musieli go w swoim domu utrzymywać ci którzy się z nim ugadzali, po zakończeniu zaś kontraktowego czasu wzmiankowany dyrektor Demoski został przy Żupańskiej Marii i Karille za czeladnika $\mathrm{w}$ winnym handlu, tym czasem rozłączywszy się kompania na dwie części nie przestawali się między sobą kłócić o rachunki. Ta niezgoda dotknęła najbardziej P. Tuszyńskiego bo kompania prosiła tutejszą Przeszłą Kamerę aby mu powierzonej do odbierania 100 talarów królewskiej dla kompani rocznej pensji nie wypłacała, więcej dodawszy na to nieznośne dla niego

51 APK, dz. cyt., s. 46.

52 Oprócz tego kusili poznańscy Grecy Sawicza stanowiskiem dziekana i pensją czterystu talarów na rok, jeśli tylko zostanie u nich kapelanem, zob.: APK, dz. cyt., sygn. 4, s. 89- 90. 
przyczyny. Tuszyński chcąc się za to zemścić przeciwnej jego partii, jeszcze bardziej zagnieździł w kompanii niezgodę, na ten sam czas wzmiankowany przeszły Dyrektor Demoski nie wiem z jakiej przyczyny odprawił się był z handlu pani Żupańskiej i Kariłły, a Tuszyński mając główną złość na ten dom i chcąc się zemścić ile możności na nim, namawia swoją partię która się zawiera w Konstantym Żupańskim i panu Leporym aby pana Demoskiego znowu zatrzymać na dyrektora i nieopowiadając tego, kontrujących stronie, uczynili urzędowy kontrakt z dyrektorem, i tenże sam kontrakt odesłali na Kamerę z aprobacją, za stancję zaś dyrektora miała być izba i alkierz do mego pomieszkania należące, co zrozumiawszy przeciwna ich strona nakazała mnie abym ja nie oddawał im klucza z tej stancji, co i uczyniłem, jednakże oni sobie w tym doradzili gdyż w niebytnośc moją otworzyli ze ślusarzem moją stancję i kazali się tam sprowadzić dyrektorowi, wszystkie ich przy tym wrzaski i zakłócenia nie mogły nic pewnego końca, jeżeli by nie weszła w to przeszła tutejsza Kamera, i dla tego na ten koniec wyznaczony był deputowanym pan Tymurol, żeby w rachunków ich zaglądanie wszedł i ich dyrektora albo utwierdził, albo nie. To wszystko względem dyrektora zakończyło się niepomyślnie, bo Tuszyński, Żupański i pan Lecpory przegrali, i tenże sam Pan Demowski został po tym przy winnym handlu u Żupańskiego za czeladnika. [...] Dyrektor który miał być w kaplicy śpiewakiem i czytelnikiem zaprzysięgną sobie nigdy w ich kaplicy po tym ani czytać ani śpiewać, i został przy Konstantym Żupańskim. Do czytania i śpiewania zaś w kaplicy mieli się stawiać Konstanty Tuszyński i Stanisław Cerowski. Bo inni do tego z Kompanii nie byli zdatni, ale Konstanty Tuszyński będąc urażony od Kompanii w rachunkach i oczerniony o to na kamerze i trzymać się swojej partii przegranej względem dyrektora, wyrzekł się był wcale i on chodzić do kościoła, a choć czasem i przyszedł nie chciał już więcej czytaniem i śpiewaniem trudnić i owszem tenże sam, jako też pan Żupański i pan Grzegorz Cepory urażali swoją przeciwnej stronie mówiąc: zobaczymy kto będzie w kościele śpiewać i czytać bez dyrektora. Więc cała nadzieja w utrzymaniu śpiewania i czytania spadła na jednego pana Stanisława Cerowskiego, ale i ten jegomość przez częste $\mathrm{w}$ te dwa lata choroby jego, jako też i za interesami handlowymi, często nie mógł być przy nabożeństwie i ja musiałem przeto na wielki mój grzech na pół msze zostawić niedokończoną, bo nie miałem z kim odprawić, a gdy nieraz protestowałem, to przeciwna strona mnie odprawiała, że kto zepsół dyrektora niech Panu Bogu rachunek za to odda" ${ }^{23}$. W trakcie kłótni i procesów doszło nawet do oskarżenia Sawicza o kradzież przedmiotów z kaplicy ${ }^{54}$.

Czas kapelaństwa w Poznaniu zakończył Atanazy Sawicz 31 stycznia 1807 r. Przez kilka miesięcy dochodził jeszcze swoich spraw w sądach i w końcu w 1808 r. przeniósł się do Kalisza, rezygnując z części wynagrodzenia na-

${ }^{53}$ APK, dz. cyt., sygn. 3, s. 93-98.

54 Tamże, s. 99-101. 
leżnego od poznańskiej wspólnoty. Swą posługę pełnił dla kaliskiej gminy w latach 1808-1827. Z jego pobytu w nadprośniańskim grodzie wiadomo na pewno, że uczestniczył w powitaniu cara Aleksandra I 10 listopada $1815 \mathrm{r}^{55}$ Papas Atanazy Sawicz zmarł 22 czerwca 1827 r., w wieku 51 lat, do śmierci pozostał w stanie bezżennym, jego jedyni krewni - brat i siostra - mieszkali w Kijowie. Był kawalerem Orderu św. Anny III klasy ${ }^{56}$.

W 1819 r. zmarł ostatni ksiądz grecki w Poznaniu nazwiskiem Zupanos. Po jego śmierci wspólnota zmuszona była sprzedać kamienicę w rynku, aby spłacić zaległe pensje spadkobiercom kapelana ${ }^{57}$.

W okresach wakatu na stanowisku kapelana gmina poznańska radziła sobie inaczej: „, [...] nieraz z Pietrkowa Xsiędza Kanonika greckiego kosztami ich sprowadzano, utrzymywano i płacono mu drogo jako też i Dziekanowi jego za edukację ich dzieci" 58 . W drugiej połowie XIX w. kapłanów sprowadzano z Lipska. Pogrzeb Jana Konstantego Żupańskiego sprawował archimandryta Kalozimos z Lipska, przy którym funkcję diaka pełnił doktor filozofii Johannitis Anthimos ${ }^{59}$.

Majątkiem kościelnym i sprawami materialnymi parafii opiekowało się specjalne kuratorium, złożone z kilku osób należących do gminy. Epitropowie opodatkowywali członków wspólnoty, prowadzili zbiórki składek oraz wydawali pieniądze na potrzeby kościoła i utrzymanie kapłanów. Co pewien czas składali ze swych czynności sprawozdania członkom gminy na wspólnych zebraniach. Od samego początku godność tę dzierżyli przedstawiciele rodziny Żupańskich, wiadomo też, że na czele kuratorów opiekujących się kaplica przez pewien okres stał Michał Kariłło ${ }^{60}$.

W roku 1795 (lub 1797) Konstanty Żupański założył cmentarz położony na północ od przedmieścia Wilda. Władze pruskie potrzebowały tego terenu na budowę fortyfikacji, dlatego w 1857 r. ofiarowały Grekom plac przy ul. Colomba (obecnie Towarowa). Aktu poświęcenia dokonał 29 sierpnia $1857 \mathrm{r}$. proboszcz gminy kaliskiej ks. Jakub Kraszanowski. Cmentarz z czasem połączył się ze świętomarcińskim i zakupiony został od rodziny Żupańskich przez parafię św. Marcina, z zastrzeżeniem nietykalności grobów prawosławnych ${ }^{61}$.

55 J. Raciborski, dz. cyt., s. 118.

${ }^{56}$ APK, dz. cyt., sygn. 7, s. 22; S. Przygodzki, Kalisz wielokulturowy, Kalisz 2012, s. 114-115.

57 Dr Zielewicz, Jan Konstanty Żupański, „Kłosy” 1884, nr 970, s. 80.

58 APK, dz. cyt., sygn. 3, s. 88-89.

${ }^{59}$ Dr Zielewicz, dz. cyt., s. 80.

${ }^{60}$ APK, dz. cyt., sygn. 3, s. 65.

${ }^{61}$ Nazwiska zmarłych pochowanych na obecnym cmentarzu świętomarcińskim: Wacław Żupański (1871-1912), z Grabowskich Maria Żupańska (zm. 1911), Leon Żupański (zm. 1873), Katarzyna z Jagielskich Żupańska (1801-1868), Konstanty Kałuba (zm. 1862), Aleksander Moraliński (zm. 1849), Anna z Żupańskich Moralińska (zm. 1848), Ferdynant Duszyński (zm. 1869), Katarzyna z Grabowskich Duczyńska (zm. 1870), Katarzyna z Jagielskich Żupańska (zm. 1871). 
Liczba poznańskiej wspólnoty zmieniała się na przestrzeni lat. W $1750 \mathrm{r}$. przebywało w Poznaniu 5 kupców greckich, w tym 2 z Egru i 3 z Tokaju, w 1760 r. liczba ich wzrosła do 23, w tym 15 przybyłych z Miszkolca, w $1770 \mathrm{r}$. nastąpił wzrost do 29, a w 1780 w wymianie handlowej uczestniczyło już 52 winiarzy pochodzenia greckiego. Pamiętać jednak trzeba, że 25 nazwisk kupców greckich powtarza się od lat sześćdziesiątych, natomiast pozostali są notowani jednorazowo ${ }^{62}$. Józef Łukaszewicz podaje, że za czasów panowania Stanisława Poniatowskiego Poznań zamieszkiwało około stu Greków ${ }^{63}$. Według spisu pruskiego z 1793 r. , miasto zamieszkiwało 47 Hellenów. Stopniowo ich liczba jednak malała, najprawdopodobniej pod wpływem asymilacji z miejscowym żywiołem, w 1816 r. było ich 32, w roku 1841 zaś tylko $15^{64}$.

Grecy poznańscy z Grekami mieszkającymi w Kaliszu tworzyli jakby jedną kolonię. Jak zauważa Adam Chodyński, mniej więcej w tym samym czasie wyemigrowali do Poznania i Kalisza z tych samych miejsc. Łączyły ich nie tylko związki krwi, lecz wspólnie prowadzone interesy. Niemal wszyscy Grecy zamieszkujący miejscowości Wielkopolski pierwotnie wywodzili się z poznańskiej lub kaliskiej wspólnoty lub byli krewnymi zamieszkałych w tych miastach rodzin ${ }^{65}$.

Poznańska gmina grecka została rozwiązana przez ostatnich jej członków: Wacława, Jana i Stefana Żupańskich, w 1909 r. ; synowie Wacława - Jerzy i Adam Żupańscy przeszli na religię rzymskokatolicką.

Grecy, mimo początkowych sporów i rywalizacji, z czasem wrośli w społeczeństwo mieszczaństwa poznańskiego i stanowili pozytywny jego składnik. O diametralnej zmianie relacji może świadczyć zdarzenie, gdy po przypadkowym zabójstwie Żyda przez Jerzego Wretowskiego w październiku 1784 r. , Polacy z biskupem Okęckim stanęli w obronie Greka. Jak najlepiej na korzyść Greków poznańskich może świadczyć fakt spolszczenia przez nich nazwisk w dobie Sejmu Czteroletniego i insurekcji kościuszkowskiej.

Najsłynniejszym przedstawicielem greckiej wspólnoty w Poznaniu jest bez wątpienia Jan Konstanty Żupański. Rodzina Żupańskich przybyła do Poznania najprawdopodobniej około roku 1770 z miejscowości Stefanopolis (wymieniana jest również miejscowość Filipopolis) w Macedonii ${ }^{66}$, pierwotnie nazywali się Żupanos (Zupanos). Dziad Jana Konstantego - Joannides Constantinides Żupanos, w przeciwieństwie do innych Greków przybył do

62 K. Kuklińska, dz. cyt., s. 39-40.

${ }^{63} \mathrm{~J}$. Łukaszewicz, dz. cyt., s. 78.

64 M. Foć, M. Romanowska, dz. cyt. , s. 14.

65 A. Chodyński, Grecy w Kaliszu, „Kaliszanin” 1891, nr 39, s. 3.

${ }^{66}$ Krystyna Kuklińska podaje, że decyzja rodziny Żupańskich o osiedleniu się w Poznaniu znajduje odbicie w źródłach węgierskich. W 1779 r. sprzedali oni w Egrze fabrykę i magazyn towarowy oraz zmienili nazwisko z Żupan na Żupański, zob.: K. Kuklińska, dz. cyt., s. 41, przyp. 17. 
Poznania razem z żoną. Zajmował się głównie handlem winem i szybko dorobił się pokaźnego majątku, już w 1803 r. zakupił kamienicę nr 58 przy Starym Rynku. Nie wiadomo, kiedy rodzina Żupańskich spolszczyła swoje nazwisko, niektórzy badacze przypuszczają, że stało się to pod wpływem wydarzeń insurekcji kościuszkowskiej, inni podają, że nastąpiło to w czasie Sejmu Wielkiego w związku ze swobodami nadanymi miastom.

Data urodzenia Żupańskiego nie jest dokładnie znana. Nekrologi, które ukazały się tuż po jego śmierci, podają rok 1801, natomiast historycy zajmujący się wydawcą, za najbardziej prawdopodobny przyjmują rok $1804^{67}$. Chrzest otrzymał z rąk Atanazego Sawicza. Okres dziecięcy i szkolny spędził Żupański w Poznaniu. W latach 1818-1826 uczęszczał do Gimnazjum św. Marii Magdaleny, w którym uczył się dobrze. W domu przyszłego wydawcy silnie kultywowane były tradycje greckie, na których straży stała matka Greczynka. Jak pisze Maria Wicherkiewiczowa, w domu znajdowały się: „[...] portrety stare $\mathrm{w}$ kontuszach i ubiorach greckich, puchary z napisami , księgi i różne przedmioty, [...] księga w którą wpisywano ważniejsze chwile i zdarzenia, jak chrzty, śluby, pogrzeby [...] księga ta w języku starogreckim została założona w roku $1775^{\prime \prime 68}$.

Po ukończeniu gimnazjum wyjechał Żupański na studia prawnicze do Berlina. Uczęszczał tam m.in. na wykłady filozofa Georga Wilhelma Friedricha Hegla. Jak zauważają autorzy jedynej dotychczas monografii o Żupańskim, kontakty zawarte przez niego w Berlinie choćby z Karolem Libeltem, Stefanem Garczyńskim i Napoleonem Kamieńskim, wpłynęły na ukształtowanie się świadomości narodowej i patriotyzmu przyszłego wydawcy ${ }^{69}$.

Po uzyskaniu tytułu sędziego w $1830 \mathrm{r}$. Żupański rozpoczął pracę jako aplikant przy Wyższym Sądzie Krajowym w Berlinie. W tym czasie współpracował też jako tłumacz i publicysta z czasopismami niemieckimi. Swoje, zazwyczaj anonimowe artykuły ogłaszał w „Hamburger Zeitung”, , Leipziger Presse” oraz w wychodzącym w Poznaniu „Polnische Correspondenz”. W publikowanych przez siebie artykułach występował jako rzecznik polskich interesów. W tym okresie podjął się również przekładu na język niemiecki dzieła Romualda Hubego Wywód praw spadkowych słowianskich; tłumaczenie opublikowano w Poznaniu w 1836 r.

W związku ze śmiercią swojego ojca Teodora w 1835 r. i przejęciem znacznego majątku Żupański powrócił do Poznania. Spełniając zapotrzebowanie społeczne, wspólnie $\mathrm{z}$ autorem ukrywającym się pod pseudonimem A.M. przełożył czterotomowe dzieło Albrechta Blocka Uwagi gospodarskie oraz już

${ }^{67}$ Szerzej na temat rozbieżności dat urodzenia Żupańskiego zob.: M. Foć, M. Romanowska, dz. cyt., s. 22, przyp. 43 i 44.

${ }^{68}$ M. Wicherkiewiczowa, dz. cyt., s. 55.

${ }^{69}$ M. Foć, M. Romanowska, dz. cyt., s. 24-25; J. Maciejewski, Jan Konstanty Żupański, w: Wybitni Wielkopolanie, pod red. W. Jakóbczyka, Poznań 1959, s. 133. 
samodzielnie O uprawie lasów Henryka Kotta. Tematykę tłumaczonych prac wiązać należy z ożywionym wtedy ruchem popularyzacji postępu w rolnictwie oraz niewykluczone - z chęcią zysku. Obie książki wydano nakładem Żupańskiego, fakt ten uznać można za początek zainteresowań księgarskowydawniczych Jana Konstantego. Przyszły wydawca obracał się w kręgu ludzi skupionych wokół Kasyna Gostyńskiego - Karola Marcinkowskiego i Spółki Bazaru, propagatorów haseł pracy organicznej. Kontakty te niewątpliwie umocniły go w przekonaniu o słuszności decyzji założenia własnej księgarni z prawami nakładczymi.

W kilka miesięcy od złożenia podania, 11 listopada 1839 r., w domu przy Starym Rynku 70, otwarta została księgarnia J.K. Żupańskiego. Początkowo zajmowała tylko jedno, ciasne pomieszczenie. W 1841 r. przeniesiono księgarnię na ul. Nową i już zaledwie rok później powstała przy niej czytelnia (wypożyczalnia), zaopatrzona głównie w dzieła francuskie i polskie. Księgarnia szybko stała się miejscem spotkań miejscowej elity kulturalnej, prężnym ośrodkiem promieniującym na cały Poznań, wsparciem dla wszelkich przejawów życia naukowego i kulturalnego. Przez 45 lat działalności Jan Konstanty wydał ponad sześćset tytułów, które ukazały się w przeszło siedmiuset tomach, o których informował w licznych anonsach prasowych i ponad pięćdziesięciu katalogach. Prawie 95\% jego własnych wydawnictw stanowiły książki polskojęzyczne. Dominowały wśród nich literatura piękna i historia, dalej: literatura religijna, społeczno-polityczna, filozoficzna, pedagogiczna, matematyczno-przyrodnicza, rolnicza, techniczna, medyczna oraz z zakresu sztuki. Swą ofertę wydawniczą firma Żupańskiego kierowała do wszystkich grup społecznych i zawodowych ${ }^{70}$. Podobnie prężnie rozwijała się czytelniawypożyczalnia.

Żupański uchodził wśród autorów za wydawcę bardzo życzliwego wobec nich. Był on jednym z niewielu wydawców, którzy w tedy z własnej inicjatywy wypłacali honoraria, zachęcali do dalszej twórczości, cierpliwie czekali na rękopisy, nie wykorzystywali naiwności autorów ${ }^{71}$, a kontakty z niektórymi, np. z Józefem Ignacym Kraszewskim, przerodziły się w prawdziwą przyjaźń. Poza tym działalność księgarza nie ograniczała się jedynie do wydawania książek. Występował on również w roli mecenasa ${ }^{72}$. Przeznaczał znaczne sumy na rzecz ubogiej polskiej emigracji i inteligencji (na jego koszt przebywał dłuższy czas w Szwajcarii Karol Libelt). Wysyłał także książki Bibliotece Polskiej w Jassach ${ }^{73}$. Prowadzenie księgarni i mecenat nie przeszkadzało Żupańskiemu w sprawowaniu ważnych funkcji obywatelskich. Od 1843 r. był

70 A. Jazdon, Jak na rynku ksiażka handlowano, „Kronika Miasta Poznania” 2003, nr tematyczny W cieniu wieży ratuszowej, s. 381-382.

${ }^{71}$ M. Foć, M. Romanowska, dz. cyt., s. 40-41.

72 W 1841 r. sprowadził do Poznania pierwszy dagerotyp.

73 Tamże, s. 41. 
członkiem Kasyna bazarowego, uczestniczył też w pracach Towarzystwa Naukowej Pomocy. Od chwili powołania w 1857 r. Poznańskiego Towarzystwa Przyjaciół Nauk wchodził w jego skład, a w latach 1867-1868 sprawował funkcję przewodniczącego Wydziału Nauk Historycznych ${ }^{74}$.

A oto jak opisywał w swych wspomnienia Jana Konstantego jego serdeczny przyjaciel Marceli Motty: „[...] osobiście należał pan Konstanty do najprzyjemniejszych ludzi, jakich mieliśmy w Poznaniu. Niewielkiego wzrostu, krzepki i zwinny, twarz miał ładną i miłą, gęstymi na tył zarzuconymi włosami odznaczoną i przypominającą bardzo twarz Mickiewicza z poznańskiego posągu Oleszczyńskiego, z czego, między nami mówiąc, bardzo był zadowolony. Uprzedzającej grzeczności dla każdego, w stosunkach bliższej przyjaźni okazywał się stałym i usłużnym jak rzadko, tak iż ci, którym zaufał, mogli w każdym razie liczyć na niego. Pogodnego przy tym usposobienia, rozmowny, biorąc żywy udział we wszystkim, witał z daleka miłym uśmiechem znajomych na ulicach i chwytał ich chętnie, wypytując lub rozpowiadając. Nie tylko w kołach polskich lubiono go powszechnie, lecz i między Niemcami i Żydami miał wielu życzliwych, chociaż do ostatnich z zasady po polsku zawsze przemawiał. Mimo różnicy religii, której wiernym pozostał raczej z tradycji familijnej aniżeli z przekonania, patriotą był szczerym i nieposzlakowanym; dlatego też, aby $z$ duchem i dążnościami prawosławia rodzina jego i współwyznawcy poznańscy w żadne nie wchodzili stosunki, w ostatnich dwudziestu latach życia nie sprowadzał, ilekroć potrzeby religijne wymagały, popów rosyjskich z Kalisza, lecz z Lipska, narodowości greckiej"75.

Ożenił się Żupański stosunkowo późno, bo dopiero w roku 1861, mając 57 lat. Pojął za żonę Katarzynę Duszyńską (także Greczynkę). Z małżeństwa tego w 1862 r. przyszedł na świat syn Stefan. Katarzyna urodziła jeszcze dwoje dzieci, które jednak w krótkim czasie zmarły ${ }^{76}$.

Swój pracowity żywot zakończył poznański „tytan książki” 30 grudnia 1883 r. o godzinie 4.00. Po jego śmierci księgarnię dalej prowadziła jego żona. W 1886 r. interes przejął syn, który zdołał prowadzić go do roku 1887. Wtedy sprzedał część zasobów Jarosławowi Leitgeberowi, a 29 listopada tegoż roku resztę książek wraz z prawami wydawniczymi zakupił Zygmunt Celichowski.

Jak dużym szacunkiem i autorytetem cieszył się Żupański (Grek z pochodzenia, Polak z przekonania), może świadczyć jego pogrzeb, który przerodził się $\mathrm{W}$ wielką manifestację patriotyczną. Tak ceremonię pogrzebową zrelacjonował „Dziennik Poznański”: „[...] Wczoraj o godzinie 2 po południu odbył się pogrzeb. Już po godzinie 1 zaczęły się zbierać małe a liczne gromadki

74 A. Kijas, Jan Konstanty Żupański zastużony księgarz i wydawca polski XIX wieku, „Księgarz” 1977, nr 2, s. 28.

${ }^{75}$ M. Motty, Przechadzki po mieście, t. I, Warszawa 1957, s. 77-78.

${ }^{76}$ M. Foć, M. Romanowska, dz. cyt., s. 43. 
osób z różnych dzielnic miasta, wśród których i poważny zastęp obywatelstwa wiejskiego dostrzedz było można; aby zasłużonemu z wszech miar mężowi, zażywającemu pośród wszystkich warstw społeczeństwa miasta naszego i Księstwa bez różnicy narodowości i religii ogólnego miru i szacunku, złożyć ostatni dowód czci wysokiej i ostatnią przysługę ziemską. To też gromadki smętnych żałobników przybrały niebawem kolosalne rozmiary i zamieniły się niemal $\mathrm{w}$ oku mgnieniu w niezliczone tłumy publiczności, złożonej z wszystkich sfer poznańskich bez różnicy wyznania i narodowości, zapełniając zupełnie szczelnie ulicę Nową i wszystkie jej przyległe zaułki oraz plac i ulicę Wilhelmowską.

Na trumnie metalowej spoczywały liczne wieńce z Warszawy, Lwowa i Krakowa oraz wieńce redakcyi »Dziennika Poznańskiego«, drukarni J. I. Kraszewskiego, księgarzy polskich z Poznania i Stowarzyszenia drukarzy polskich.

Kondukt prowadził, w asystencyi dwóch konstablerów w celu utrzymania porządku wykomenderowanych, archimandryta z Lipska Kolosimos z pomocnikiem swym dr. fil. Johanidesem Asthimos. Za trumną postępowała rodzina zmarłego, deputacye z Warszawy, Lwowa i Krakowa oraz bardzo liczni przyjaciele i znajomi, tudzież p. burmistrz Herse na czele licznych członków magistratu i reprezentacji miejskiej.

Kiedy orszak żałobny przybył na miejsce swego przeznaczenia, tylko bardzo nieznaczna liczba mogła wejść na cmentarz z powodu nader szczupłej przestrzeni jego. Wśród wrzawy i ogólnego zamieszania i w czasie obrzędów według rytuału greckiego nad grobem zmarłego dokonywanych, zamknęła policya bramę cmentarza, a zbite tłumy publiczności, do kilku tysięcy liczącej, zaległy szeroką drogę cmentarną, rozlewając się z wolna na wszystkie strony i opuszczając ze smutkiem miejsce wiecznego spoczynku nieboszczyka $[\ldots]^{\prime \prime 77}$.

Marcin Mikołajczyk

\section{Grecka diaspora w Poznaniu w XVIII i XIX w.}

\section{Streszczenie}

Poznań, jedno z największych miast Rzeczypospolitej, licznie zamieszkiwali przybysze z innych krajów. Wśród nich byli Grecy. Głównymi przyczynami emigracji greckiej były przesłanki natury ekonomicznej, politycznej oraz geopolitycznej.

\footnotetext{
77 Jan Konstanty Żupański, wspomnienie pośmiertne, „Dziennik Poznański” 1884, nr 3.
} 
Niezwykle interesującym problemem pozostaje pochodzenie etniczne emigrantów. Pierwsze wzmianki o Grekach w mieście pochodzą z XVI w. Znacznie liczniej napłynęli Grecy do miasta w drugiej poł. XVIII w.

Głównym zajęciem emigrantów był intratny handel winem oraz towarami wschodnimi. Grecy sprowadzali wino najczęściej z ośrodków węgierskich.

Od chwili przybycia do Poznania Grecy postrzegani byli przez rodzime kupiectwo jako czynnik niepożądany. Księgi grodzkie Poznania oraz Konfraterni Kupieckiej przepełnione są skargami na przybyszów z południa. Dopiero ustawy działającej w Poznaniu Komisji Dobrego Porządku z 1780 r. uregulowały warunki pobytu Greków w mieście.

Poznańska gmina założona została ok. 1750 r. Poznańscy grecy byli chrześcijanami wyznania prawosławnego. Nabożeństwa odprawiano w cerkwiach domowych, gmina posiadała cmentarz. Kolejnymi kapelanami gminy byli: Atanazy Korda, Konstantyn Chartofilax Okuta, Atanazy Sawicz oraz Zupanos.

Poznańska gmina grecka została rozwiązana w 1909 r.

Najsłynniejszym przedstawicielem poznańskich Greków był Jan Konstanty Żupański, księgarz i wydawca.

\title{
Greek diaspora in Poznan in the $18^{\text {th }}$ and $19^{\text {th }}$ century
}

\begin{abstract}
Poznań, one of the largest Polish cities, was frequently inhabited by citizens of other countries. One such nation were Greeks, who came to Poland for economic, political and geopolitical reasons.

Ethnic origins of emigrants remains an interesting problem. The first information on Greeks in Poznan can be traced back to the $16^{\text {th }}$ century. In the second half of the $17^{\text {th }}$ century, the number of Greeks coming to the city increased.

Emigrants occupied themselves mainly with (profitable) wine and Eastern goods trade. Greeks imported wine mostly from Hungary.

From the moment they came, Greeks were considered unwelcome by local tradesmen. Municipal books and the books of the Merchants' Guild are full of complaints on the incomers from the South. It was not until 1789, when the laws of the Commission of Good Order operating in Poznań, that the conditions of Greeks staying in Poznań had been regulated.

The Poznań Greek community was established around 1750. Poznań Greeks were of the Christian Orthodox denomination. Services were held at home churches, the community also had its cemetery. The following people were the chaplains: Atanazy Korda, Konstantyn Chartofilax Okuta, Atanazy Sawicz and Zupanos.

The Poznań Greek community was dissolved in 1909.

The most well-known representative of the Poznań Greeks is Jan Konstanty Żupański, a bookseller and publisher.
\end{abstract}

Key words: Greeks, diaspora, Poznań, Jan Konstanty Żupański 